\title{
Pengaruh Pemilihan Lokasi, Daya Beli Konsumen dan Suasana terhadap Keputusan Pedagang Kaki lima Berjualan di Jalan H.O.S Cokroaminoto Kota Kediri
}

\author{
Baju Pramutoko \\ Prodi Manajemen, Fakultas Ekonomi Universitas Islam Kadiri Kediri
}

\begin{abstract}
The formulation of the problem in this study is whether there is a relationship, pengauruh and which variables are dominant influencing between selling locations, consumer purchasing power and atmosphere towards the decisions of street vendors selling on Jalan H.O.S Cokroaminoto, Kediri City. This research was conducted for 3.5 months, starting from early January to mid-April 2021. The population in this study were all street vendors / PK5 who sell in the morning, afternoon, evening and night on Jalan H.O.S Cokroaminoto. which amounted to about 500 traders. While the sample in this study amounted to 83 people. The variables in this study are (X1) Selling Location, (X2) Consumer Purchasing Power, (X3) Atmosphere with Bound Variables (Y) The decision of PK5 traders to choose to sell on Jl. HOS Cokroaminoto. Data analysis techniques in this study are a) Validity Test, b) Reliability Test, c) Multiple Correlation Test, and c) Multiple Linear Regression Test.

The results of this study is the test results using statistics, it is known that the multiple correlation coefficient is 0.808. This shows that the internal factors of consumer behavior which consist of Selling Location (X1), Consumer Purchasing Power (X2), and Place of Selling Atmosphere (X3) have a relationship with PK5's decision to choose to sell on Jalan HOS Cokroaminoto Kediri. The test results with multiple linear regression, it is known that the regression equation affects the location of sales (X1), consumer purchasing power (X2), and the atmosphere of places of sale $(X 3)$ is $Y=4.193+0.314 X 1+0.362 X 2+0.117 X 3$. And it can be concluded that the variable X2, consumer purchasing power has the most dominant influence on PK5's decision to choose to sell on Jalan HOS Cokroaminoto Kediri. Keywords: Selling locations, consumer purchasing power, atmosphere and the decision to sell
\end{abstract}

\begin{abstract}
Abstrak
Rumusan Masalah dalam penelitian ini adalah Apakah terdapat hubungan, pengauruh dan mana variabel yang dominan berpengaruh antara Lokasi berjualan, Daya Beli Konsumen dan Suasana Terhadap Keputusan Pedagang Kaki lima berjualan di Jalan H.O.S Cokroaminoto Kota Kediri. Penelitian ini dilakukan selama 3,5 bulan, mulai awal bulan Januari sampai pertengahan bulan April 2021. Populasi dalam penelitian ini adalah seluruh pedagang kaki lima/PK5 yang berjualan pada pagi, siang, sore dan malam hari di Jalan H.O.S Cokroaminoto. yang berjumlah sekitar 500 pedagang. Sedangkan sampel dalam penelitian ini berjumlah 83 orang. Adapun variabel dalam penelitian ini adalah $\left(\mathrm{X}_{1}\right)$ Lokasi Berjualan, $\left(\mathrm{X}_{2}\right)$ Daya Beli Konsumen, $\left(\mathrm{X}_{3}\right)$ Suasana dengan Variabel Terikat $(\mathrm{Y})$ Keputusan pedagang PK5 memilih berjualan di Jl. HOS Cokroaminoto. Teknik Analisi Data dalam penelitian ini adalah a) Uji Validitas, b) Uji Reabilitas, c) Uji Korelasi Berganda, dan c) Uji Regresi linier berganda.
\end{abstract}


Hasil penelitian ini adalah Hasil pengujian menggunakan statistik diketahui koefisien korelasi berganda sebesar 0,808. Hal ini menunjukkan bahwa faktor-faktor internal prilaku konsumen yang terdiri dari Lokasi Berjualan $\left(\mathrm{X}_{1}\right)$, Daya Beli Konsumen $\left(\mathrm{X}_{2}\right)$, dan Suasana Tempat Berjualan $\left(\mathrm{X}_{3}\right)$ mempunyai hubungan terhadap keputusan PK5 memilih berjualan di Jalan HOS Cokroaminoto Kediri. Hasil pengujian dengan regresi linier berganda diketahui persamaan regresi berpengaruh antara Lokasi Berjualan $\left(X_{1}\right)$, Daya Beli Konsumen $\left(X_{2}\right)$, dan Suasana Tempat Berjualan $\left(X_{3}\right)$ adalah $Y=4,193+0,314$ $\mathrm{X}_{1}+0,362 \mathrm{X}_{2}+0,117 \mathrm{X}_{3}$. Dan dapat disimpukan bahwa variabel $\mathrm{X} 2$, Daya beli konsumen berpengaruh paling dominan terhadap keputusan PK5 memilih berjualan di Jalan HOS Cokroaminoto Kediri.

Kata Kunci : Lokasi Berjualan, Daya Beli Konsumen, Suasana dan keputusan berjualan.

\begin{tabular}{lcl}
\hline Permalink/DOI & $:$ & http://dx.doi.org/10.32503/jmk.v6i2.1585 \\
Sejarah Artikel & $:$ & Artikel diterima (18 April 2021); direvisi (1 Mei 2021); \\
& disetujui (19 Mei 2021) \\
Email & $:$ & byugold@gmail.com \\
\hline
\end{tabular}

\section{Pendahuluan}

Aktivitas perekonomian masyarakat seakan mati suri ketika terjadi Pandemi Virus Corona pada awal tahun 2020 yang kemudian dikenal dengan Covit 19, karena Virus corona ini ditemukan pertama kali di Wuhan China pada akhir tahun 2019. Tidak ada yang mampu memprediksi kejadian adanya Covit 19 yang pada perkembangannya menyebar ke seluruh dunia sebagai pandemi global. Kemudian penerapan aturan kesehatan dilakukan yaitu dengan menerapkan protokol kesehatan (Prokes) yaitu dengan cara menggunakan masker, sering mencuci tangan, menjauhi kerumunan dan membatasi aktivitas atau mobilitas warga. Dengan protokol kesehatan ini diharapkan bisa mengurangi tingkat penularan covit 19 ini.

Untuk menghindari penyebaran penularan Covit 19 ini perbagai cara antisipasi dilakukan dengan mengurangi aktivitas di luar rumah, tidak boleh bepergian semenjak virus ini merebak, hampir semua negara menerapkan aturan untuk stay at home atau tinggal dirumah, pekerjaan dilakukan dari dalam rumah akhirnya dikenal dengan istilah work from home yang secara otomatis aktivitas kehidupan masyarakat juga lumpuh. Kantor pemerintahan dan swasta tutup, pabrikpabrik tutup, Sekolah-sekolah tutup, perguruan-perguruan tinggi tutup, pasar-pasar tutup, mall dan swalayan tutup, tempat-tempat wisata tutup, warung restoran dan cafe tutup. Akibat yang ditimbulkan sektor ekonomi yang lumpuh dengan pandemi ini. Karena tidak ada aktivitas produksi di pabrik, tidak ada jual beli dengan normal, terjadilah kelangkaan barang harga-harga dipasar menjadi naik tajam.

Selama 6 bulan dan ditambah 6 bulan berikutnya ditahun 2020 perbagai pembatasan aktivitas pergerakan manusia dilakukan, seperti dilarang bepergian keluar kota, dilarang mudik saat lebaran hari raya umat beragama dan lain sebagainya yang menimbulkan kerumunan massa dilarang dan akan ditindak tegas 
oleh aparat pemerintah. Namun manusia membutuhkan aktivitas untuk mempertahan hidup, kalau tidak bekerja dan berusaha mereka masyarakat akan makan apa, terutama masyarakat dengan keterbatasan ekonomi, bantuan dari pemerintah atau negara juga tidak seterusnya mereka terima karena ada keterbatasan anggaran. Sehingga walaupun ada larangan mereka akhirnya tetap melakukan aktivitas perdagangan walaupun dilakukan pembatasan waktu dagang mereka misalnya pembatasan jumlah pedagang di zona zona tertentu, penutupan jalan setiap malam Sabtu dan malam Minggu dimulai pukul 18.00 sampai dengan pukul 21.00 dengan cara itu diharapkan aktivitas warga masyarakat bisa dibatasi, sehingga penularan covit 19 bisa ditekan serendah mungkin, tetapi warga masyarakat bisa bekerja dan berdagang, terutama sektor UMKM pedagang kaki lima yang hanya mengandalkan dagangannya laku di hari itu.

Di wilayah kota Kediri, aktifitas masyarakat tetap berlangsung seperti biasa, namun juga ada peraturan - peraturan dari pemerintah kota Kediri dalam upaya untuk menekan penularan Covit 19 di masyarakat. Pembatasan tempat perdagangan agar tidak terjadi kerumunan terus dilakukan pengawasan oleh aparat satpol PP dan dari pihak kepolisian. Beberapa ruas jalan di kota Kediri yang menjadi pusat perdagangan kaki lima /PKL juga dilakukan pembatasan jam operasi seperti di Jaolan Terusan Kaliombo, jalan Kilisuci, Jl. Joyoboyo, Jl. Hayam Wuruk, Jl. Dhoho,Jl. Brawijaya, Jl. Panglima Polim, Jl. Panglima Sudirman, Jl. Urip Sumoharjo, Jl. Wahid Hasyim, Jl. Patimura, Jl. HOS. Cokroaminoto, Jl.Letjend Suprapto, Jl. P.K. Bangsa dan beberapa ruas jalan lain yang sering menjadi tempat berjualan.

Namun tidak semua ruas jalan di kota Kediri menjadi favorit pedagang kaki lima untuk berjualan, walupun ada yang berjualan tetapi penghasilan PK5 tersebut tidak bisa maksimal, sehingga pemilihan lokasi berjualan menjadi salah satu kunci dagangan mereka laris. Penentuan lokasi usaha perlu dipertimbangkan dengan baik. Lokasi yang strategis salah satu faktor penting dalam menentukan keberhasilan suatu usaha. Hurriyati (2005) menyebutkan soal Pemilihan tempat atau lokasi memerlukan pertimbangan yang cermat terhadap beberapa faktor berikut:

a. Akses, misalnya lokasi yang mudah dijangkau sarana transportasi umum.

b. Visibilitas, misalnya lokasi yang dapat dilihat dengan jelas dari tepi jalan.

c. Lalu lintas (traffic), di mana ada dua hal yang perlu dipertimbangkan, yaitu: (1) banyaknya orang yang lalu lalang dapat memberikan peluang besar terjadinya impluse buying, (2) kepadatan dan kemacetan lalu lintas dapat pula menjadi hambatan.

d. Tempat parkir yang luas dan aman.

e. Ekspansi, tersedia tempat yang cukup untuk perluasan usaha di kemudian hari.

f. Lingkungan, yaitu daerah sekitar yang mendukung jasa yang ditawarkan.

g. Persaingan, yaitu lokasi pesaing.

h. Peraturan pemerintah. 
Selanjutnya daya beli konsumen juga merupakan bagian penting yang juga perlu diperhatikan, karena kemampuan membeli konsumen di suatu wilayah akan juga mempengaruhi keberhasilan dalam usaha. Seperti yang dikemukan oleh Iskandar Putong (2013), daya beli konsumen adalah kemampuan konsumen dalam membeli banyaknya jumlah barang yang diminta pada suatu pasar tertentu dengan tingkat harga tertentu pada tingkat pendapatan tertentu dan dalam periode tertentu.

Selain itu factor suasana juga menjadi keberhasilan dalam usaha, kalau dikaitkan dengan usaha PK5 suasana tempat usaha yang nyaman akan mendorong konsumen untuk datang membeli dagangan mereka, tanpa ganguan yang dapat menghambat konsumen datang. Menurut Kotler (2005). Suasana tempat berdagang mempengaruhi keadaan emosi pembeli yang menyebabkan atau mempengaruhi pembelian. Keadaan emosional akan membuat dua perasaan yang dominan yaitu perasaan senang dan membangkitkan keinginan.

Jalan HOS. Cokroaminoto pasar Pahing kota Kediri merupakan salah satu tempat ruas jalan sepanjang $1 \mathrm{~km}$, mulai dari barat perempatan Retco Pentung menuju ketimur hingga pertigaan Jl. Letjend Suprapto Kelurahan Burengan, yang mempunyai banyak pedagang Kaki lima, dengan bermacam - macam produk yang mereka perdagangkan, mulai dari buah,roti, angkringan, nasi goreng, tahu lontong dll. Aktifitas pedagang PKL itu mulai dari pagi hingga malam hari sampai sekitar jam 12 malam yang saling bergantian. Sehingga ruas jalan HOS. Cokroaminoto itu menjadi pusat perdagangan PKL yang paling ramai di kota Kediri.

Berdasarkan dari latar belakang dan kondisi tersebut diatas, maka peneliti membatasi hanya pada permasalahan manajemen pemasaran yang difokuskan pada Pengaruh Lokasi berjualan, Daya Beli Konsumen, dan Suasana Terhadap Keputusan Pedagang Kaki lima berjualan di Jalan H.O.S Cokroaminoto Kota Kediri.

\section{Metode Penelitian}

Penelitian ini dilakukan di ruas jalan H.O.S. Cokroaminoto, dimana letaknya adalah di seputar Pasar Paing Kecamatan Pesantren Kota Kediri. Jenis penelitian ini adalah penelitian lapangan dengan tujuan untuk mengetahui hubungan dan pengaruh antara Pemilihan Lokasi, Daya Beli Konsumen dan Suasana Terhadap Keputusan Pedagang Kaki lima berjualan di Jalan H.O.S Cokroaminoto Kota Kediri.

Penelitian ini dilakukan selama 3,5 bulan, mulai awal bulan Januari sampai Pertengahan bulan April 2021. Populasi dalam penelitian ini adalah seluruh pedagang kaki lima/PK5 yang berjualan dan menggelar dagangannya secara bergiliran pada pagi, siang, sore dan malam hari di Jalan H.O.S Cokroaminoto Kota Kediri yang berjumlah sekitar 500 pedagang. Untuk Teknik pengambilan sampel yang digunakan dalam penelitian ini adalah sampling 
aksidental. teknik sampling aksidental adalah teknik pengambilan sampel dimana penentuan jumlah sampel berdasarkan kebetulan, yaitu siapa saja yang secara kebetulan bertemu dengan peneliti yang dapat digunakan sebagai sampel. Untuk penentuan sampelnya, dengan menggunakan rumus slovin, yaitu :

$\mathrm{n}=\frac{N}{1+\left(N \times e^{2}\right)}$ dengan margin eror $10 \% \cdot \mathrm{n}=\frac{500}{1+\left(500 \times 0.1^{2}\right)}=\frac{1500}{1+5}$ $=\frac{500}{6} \mathrm{n}=83,33$.

Setelah dihitung dicapai jumlah sampel sebesar 83 Pedagang PK5.

Metode pengumpulan data yang digunakan dalam penelitian ini adalah sebagai berikut:

1. Data Primer, data asli yang dikumpulkan dengan melalui :

a. Observasi, pengamatan langsung yaitu dengan cara pengumpulan data melalui pencatatan secara cermat dan sistematis langsung dilokasi obyek penelitian.

b. Wawancara, yaitu dengan cara pengumpulan data melalui Tanya jawab langsung dengan responden di obyek penelitian.

c. Kuisener, yaitu pengumpulan data dengan menyebaran kuisener kepada responden di obyek penelitian.

2. Data Sekunder (data tersedia) dikumpulkan melalui cara :

a. Dokumentasi data yang diperoleh dari badan atau dinas pemerintah yang terkait dengan obyek penelitian.

b. Studi kepustakaan, yaitu dengan membaca dan mempelajari dari bukubuku literature, artikel dan makalah seminar.

Peneliti memperoleh langsung data-data yang dibutuhkan berdasarkan dari keterangan dan informasi yang diberikan responden melalui angket (kuesioner) yang telah disebarkan dengan metode skor, pemberian skor ini digunakan sistem skala likert. Dengan membuat pernyataan dengan diberi skor :Jawaban a (sangat setuju) diberi skor 4, Jawaban b (setuju ) diberi skor 3, Jawaban c (tidak setuju)diberi skor 2, Jawaban d (sangat tidak setuju) diberi skor 1.

Adapun variabel-variabel dalam penelitian ini adalah :

a) Varibel Bebas, dalam penelitian ini yang menjadi variabel bebas adalah :

$\left(\mathrm{X}_{1}\right)$ Lokasi Berjualan

$\left(\mathrm{X}_{2}\right)$ Daya Beli Konsumen

$\left(\mathrm{X}_{3}\right)$ Suasana Tempat Berjualan

b) Variabel Terikat dalam penelitian ini keputusan pedagang PK5 memilih berjualan di Jl. HOS Cokroaminoto Kota Kediri. 
Teknik Analisis Data yang diginakan dalam penelitian ini adalah Uji Validitas, Uji Reabilitas, Uji Korelasi Berganda, dan Uji Regresi linier berganda. Dengan perhitungan menggunakan bantuan program computer SPSS versi 23.

1. Uji Validitas, digunakan untuk mengukur sah dan valid tidaknya suatu kuesioner. Suatu koesioner dianggap valid jika pertanyaan pada kuesioner mampu mengungkapkan sesuatu yang diukur oleh kuesioner. (Ghozali, 2001). Dalam hal ini digunakan item pertanyaan yang diharapkan dapat secara tepat mengungkapkan variabel yang diukur.

2. Uji Reliabilitas adalah pengujian untuk mengukur suatu kuesioner yang merupakan indikator dari variabel. Suatu kuesioner dikatakan reliabel atau handal jika jawaban seseorang terhadap pertanyaan adalah konsisten atau stabil dari waktu ke waktu. Struktur variabel dikatakan reliabel jika memberikan nilai Cronbach Alpha > 0,60.(Ghozali, 2006).

3. Uji Korelasi Berganda, Alat analisis ini digunakan untuk mengetahui adakah hubungan secara simultan antara variabel bebas $\left(\mathrm{X}_{1}\right.$ dan $\left.\mathrm{X}_{2}\right)$ dengan variabel terikat yaitu minat beli konsumen (Y),

4. Analisis Regresi Linier berganda, Untuk mengetahui pengaruh variabel bebas terhadap variabel terikatnya. Dengan :

a. Uji Signifikasi Simultan (Uji F), untuk mengetahui pengaruh variabel bebas terhadap variabel terikat secara simultan (bersama) digunakan uji $\mathrm{F}$ dengan persamaan.

b. Uji Parsial (Uji t), Uji t adalah suatu metode atau cara yang digunakan untuk menguji apakah hipotesis yang diajukan oleh penulis terbuktu benar dan dapat dipercaya atau sebaliknya.

\section{Hasil dan Pembahasan}

Setelah dilakukan serangkain kegiatan penelitian dilapangan dengan penyebaran kuisener dan wawancara kepada 83 responden pedagang PK5 yang mangkal di jalan HOS. Cokroaminoto Kota Kediri itu, dapat dijelaskan hasilnya sebagai berikut :

\section{a. Distribusi Frekwensi Variabel X1- Lokasi Berjualan}

\begin{tabular}{|c|c|c|c|c|c|}
\hline Item & Pernyataan & SS & $S$ & $\mathrm{TS}$ & STS \\
\hline 1 & $\begin{array}{l}\text { Jl. HOS. Cokroaminoto Kota Kediri } \\
\text { adalah lokasi yang mudah dijangkau } \\
\text { konsumen }\end{array}$ & $\begin{array}{c}21 \\
(25 \%)\end{array}$ & $\begin{array}{l}50 \\
(60 \%)\end{array}$ & $\begin{array}{c}12 \\
(15 \%)\end{array}$ & - \\
\hline 2 & $\begin{array}{l}\text { Visibilitas, Jl. HOS. Cokroaminoto } \\
\text { Kota Kediri, lokasi yang dapat dilihat } \\
\text { dengan jelas dari tepi jalan. }\end{array}$ & $\begin{array}{c}24 \\
(29 \%)\end{array}$ & $\begin{array}{c}55 \\
(66 \%)\end{array}$ & $\begin{array}{c}4 \\
(5 \%)\end{array}$ & - \\
\hline 3 & $\begin{array}{l}\text { Di Jl. HOS. Cokroaminoto, lalu } \\
\text { lintasnya banyak orang yang lalu } \\
\text { lalang yang dapat memberikan } \\
\text { peluang besar terjadinya pembelian }\end{array}$ & $\begin{array}{c}59 \\
(70 \%)\end{array}$ & $\begin{array}{c}24 \\
30 \%\end{array}$ & - & - \\
\hline
\end{tabular}




\begin{tabular}{|c|c|c|c|c|c|c|}
\hline 4 & $\begin{array}{l}\text { Di J1. HOS. Cokroaminoto } \\
\text { parkir yang luas dan aman. }\end{array}$ & Tempat & $\begin{array}{c}34 \\
(41 \%) \\
\end{array}$ & $\begin{array}{l}47 \\
(57 \%)\end{array}$ & $\begin{array}{c}2 \\
(2 \%) \\
\end{array}$ & - \\
\hline 5 & $\begin{array}{l}\text { Lingkungan di Jl. } \\
\text { Cokroaminoto, mendukung } \\
\text { dan jasa yang ditawarkan }\end{array}$ & $\begin{array}{r}\text { HOS. } \\
\text { barang }\end{array}$ & $\begin{array}{c}47 \\
(57 \%)\end{array}$ & $\begin{array}{l}36 \\
(43 \%)\end{array}$ & - & - \\
\hline
\end{tabular}

Sumber: Data Primer yang Diolah, 2021

\section{b. Distribusi Frekwensi Variabel X2- Daya Beli Konsumen :}

\begin{tabular}{clcccc}
\hline Item & \multicolumn{1}{c}{ Pernyataan } & SS & S & TS & STS \\
\hline 1 & Harga barang yang saya inginkan & 36 & 42 & 5 & - \\
& dipasar sesuai kemampuan saya. & $(3 \%)$ & $(51 \%)$ & $(6 \%)$ & - \\
\hline 2 & Harga barang - barang dipasar sesuai & 35 & 43 & 5 & - \\
& keinginan saya & $(42 \%)$ & $(52 \%)$ & $(6 \%)$ & - \\
\hline 3 & Saya mampu membeli barang sesuai & 34 & 43 & 6 & - \\
& dengan Pendapatan bulanan saya & $(41 \%)$ & $(52 \%)$ & $(7 \%)$ & - \\
\hline 4 & Saya Membeli barang sesuai dengan & 42 & 35 & 6 & - \\
& keinginan dan selera & $(51 \%)$ & $42 \%$ & $(7 \%)$ & - \\
\hline 5 & $\begin{array}{l}\text { Di masa datang harga-harga barang } \\
\text { akan naik }\end{array}$ & 51 & 26 & 6 & - \\
& Dat Prim) & $(31 \%)$ & $(7 \%)$ & - \\
\hline
\end{tabular}

Sumber: Data Primer yang Diolah, 2021

\section{c. Distribusi Frekwensi Variabel X3- Suasana :}

\begin{tabular}{|c|c|c|c|c|c|}
\hline Item & Pernyataan & SS & $S$ & TS & STS \\
\hline 1 & $\begin{array}{l}\text { Kondisi jalan HOS. Cokroaminoto } \\
\text { lebar dan bersih. }\end{array}$ & $\begin{array}{c}20 \\
(24 \%)\end{array}$ & $\begin{array}{l}45 \\
(54 \%)\end{array}$ & $\begin{array}{c}17 \\
(21 \%)\end{array}$ & $\begin{array}{c}1 \\
(1 \%)\end{array}$ \\
\hline 2 & $\begin{array}{l}\text { Jalan HOS. Cokroaminoto nyaman } \\
\text { untuk berjualan. }\end{array}$ & $\begin{array}{c}22 \\
(26 \%)\end{array}$ & $\begin{array}{c}58 \\
(70 \%)\end{array}$ & $\begin{array}{c}3 \\
(4 \%)\end{array}$ & - \\
\hline 3 & $\begin{array}{l}\text { Jalan HOS. Cokroaminoto ramai lalu } \\
\text { lintas orang dan dekat dengan Pasar } \\
\text { Paing. }\end{array}$ & $\begin{array}{c}18 \\
(22 \%)\end{array}$ & $\begin{array}{c}58 \\
(70 \%)\end{array}$ & $\begin{array}{c}7 \\
(8 \%)\end{array}$ & $\begin{array}{l}- \\
-\end{array}$ \\
\hline 4 & $\begin{array}{l}\text { Jalan HOS. Cokroaminoto Aman dari } \\
\text { gangguan karena ada didekat } \\
\text { perkampungan penduduk. }\end{array}$ & $\begin{array}{c}24 \\
(30 \%)\end{array}$ & $\begin{array}{c}55 \\
(65 \%)\end{array}$ & $\begin{array}{c}4 \\
(5 \%)\end{array}$ & - \\
\hline 5 & $\begin{array}{l}\text { Penataan PK5 di HOS. Cokroaminoto } \\
\text { baik dan toleran. }\end{array}$ & $\begin{array}{c}36 \\
(43 \%)\end{array}$ & $\begin{array}{l}45 \\
(54 \%)\end{array}$ & $\begin{array}{c}2 \\
(3 \%)\end{array}$ & - \\
\hline
\end{tabular}

Sumber: Data Primer yang Diolah,2021

\section{d. Distribusi Frekwensi Variabel Y- Keputusan Memilih lokasi berjualan :}

\begin{tabular}{clcccc}
\hline Item & \multicolumn{1}{c}{ Pernyataan } & SS & S & TS & STS \\
\hline 1 & $\begin{array}{l}\text { Jl. HOS. Cokroaminoto Kota Kediri } \\
\text { adalah lokasi yang mudah dijangkau } \\
\text { konsumen }\end{array}$ & $\begin{array}{c}35 \\
(42 \%)\end{array}$ & $\begin{array}{c}43 \\
(52 \%)\end{array}$ & $\begin{array}{c}5 \\
(6 \%)\end{array}$ & - \\
& $\begin{array}{l}\text { Lingkungan di Jl. HOS. Cokroaminoto, } \\
\text { mendukung barang dan jasa yang } \\
\text { ditawarkan }\end{array}$ & 41 & 36 & 6 & - \\
\hline 2 & $(50 \%)$ & $(43 \%)$ & $(7 \%)$ & - \\
\hline
\end{tabular}




\begin{tabular}{llccll}
\hline 3 & $\begin{array}{l}\text { Harga barang yang saya inginkan } \\
\text { dipasar sesuai kemampuan saya. }\end{array}$ & $\begin{array}{c}43 \\
(52 \%)\end{array}$ & $\begin{array}{c}40 \\
(48 \%)\end{array}$ & $\begin{array}{l}- \\
-\end{array}$ & - \\
\hline 4 & Saya Membeli barang sesuai dengan & 40 & 43 & - & - \\
& keinginan dan selera & $(48 \%)$ & $(52 \%)$ & - & - \\
\hline 5 & Jalan HOS. Cokroaminoto ramai lalu & 53 & 30 & - & - \\
& lintas orang dan dekat dengan Pasar & $(64 \%)$ & $(36 \%)$ & - & - \\
& Paing.
\end{tabular}

Sumber: Data Primer yang Diolah,2021

\section{Uji Validitas}

Uji validitas digunakan untuk menguji sejauh mana ketepatan alat pengukur dapat mengungkapkan konsep gejala atau kejadian yang di ukur.

\section{Tabel 1}

Uji Validitas

\begin{tabular}{|c|c|c|c|}
\hline Variabel/item & $\begin{array}{c}\text { Nilai Korelasi } \\
\text { (Pearson } \\
\text { Corellation) }\end{array}$ & $\begin{array}{c}\text { Probabilitas } \\
\text { Korelasi [(sig. (2- } \\
\text { tailed)] }\end{array}$ & Kesimpulan \\
\hline \multicolumn{4}{|c|}{ Variabel Lokasi Berjualan $\left(\mathrm{X}_{1}\right)$} \\
\hline Item $X_{1}$ ke 1 & 0,647 & 0,000 & Valid \\
\hline Item $X_{1}$ ke 2 & 0,716 & 0,000 & Valid \\
\hline Item $X_{1}$ ke 3 & 0,774 & 0,000 & Valid \\
\hline Item $\mathrm{X}_{1}$ ke 4 & 0,686 & 0,000 & Valid \\
\hline Item $X_{1}$ ke 5 & 0,742 & 0,000 & Valid \\
\hline \multicolumn{4}{|c|}{ Variabel Daya Beli Konsumen $\left(\mathrm{X}_{2}\right)$} \\
\hline Item $\mathrm{X}_{2}$ ke 1 & 0,754 & 0,000 & Valid \\
\hline Item $X_{2}$ ke 2 & 0,734 & 0,000 & Valid \\
\hline Item $X_{2}$ ke 3 & 0,708 & 0,000 & Valid \\
\hline Item $\mathrm{X}_{2}$ ke 4 & 0,701 & 0,000 & Valid \\
\hline Item $X_{2}$ ke 5 & 0,640 & 0,000 & Valid \\
\hline \multicolumn{4}{|c|}{ Variabel Suasana tempat berjualan $\left(\mathrm{X}_{2}\right)$} \\
\hline Item $X_{3}$ ke 1 & 0,653 & 0,000 & 0,000 \\
\hline Item $X_{3}$ ke 2 & 0,642 & 0,000 & 0,000 \\
\hline Item $X_{3}$ ke 3 & 0,653 & 0,000 & 0,000 \\
\hline Item $\mathrm{X}_{3}$ ke 4 & 0,728 & 0,000 & 0,000 \\
\hline Item $X_{3}$ ke 5 & 0,651 & 0,000 & 0,000 \\
\hline \multicolumn{4}{|c|}{ Variabel Keputusan Pemilihan Berjualan di HOS. Cokroaminoto (Y) } \\
\hline Item Y ke 1 & 0,694 & 0,000 & Valid \\
\hline Item Y ke 2 & 0,691 & 0,000 & Valid \\
\hline Item Y ke 3 & 0,574 & 0,000 & Valid \\
\hline Item Y ke 4 & 0,457 & 0,000 & Valid \\
\hline Item Y ke 5 & 0,514 & 0,000 & Valid \\
\hline
\end{tabular}

Sumber: Data primer yang diolah, 2021

Tabel 1 menunjukkan hasil pengujian validitas diatas bahwa semua item pertanyaan untuk variabel lokasi berjualan $\left(\mathrm{X}_{1}\right)$, variabel daya beli konsumen $\left(\mathrm{X}_{2}\right)$, variabel suasana tempat berjualan $\left(\mathrm{X}_{3}\right)$ dan variabel keputusan Pemilihan Berjualan 
di HOS. Cokroaminoto (Y) mempunyai nilai korelasi yang lebih besar 0,3 serta diperkuat dengan probabilitas korelasi [(sig. (2-tailed)] 0,000, maka dapat dikatakan bahwa keseluruhan item variabel penelitian dikatakan valid untuk digunakan sebagai instrumen dalam penelitian atau pertanyaan-pertanyaan yang diajukan dapat digunakan untuk mengukur variabel yang diteliti.

\section{Uji Reliabilitas}

Pengujian reliabilitas dalam penelitian ini adalah dengan menggunakan rumus Alpha. Hasil pengujian reliabilitas untuk masing-masing variabel dapat diringkas pada tabel 2, sebagai berikut:

Tabel 2

Uji Reliabilitas

\begin{tabular}{lcc}
\hline Variabel & $\begin{array}{c}\text { Nilai Cronbach's Alpha } \\
\text { Based on Standardized } \\
\text { Item }\end{array}$ & Keterangan \\
\hline Lokasi & 0,758 & Reliabel \\
\hline Daya beli konsumen & 0,749 & Reliabel \\
\hline Suasana tempat berjualan & 0,675 & Reliabel \\
\hline Keputusan Pemilihan Berjualan di Jl. & 0,625 & Reliabel \\
\hline HOS. Cokroaminoto & & \\
\hline
\end{tabular}

Sumber: Data primer yang diolah, 2021

Hasil uji reliabilitas tersebut menunjukkan bahwa semua variabel mempunyai koefisien Alpha yang cukup besar yaitu diatas 0,60 sehingga dapat dikatakan semua konsep pengukur masing-masing variabel dari kuesioner adalah reliabel sehingga untuk selanjutnya item-item pada masing-masing konsep variabel sebagai alat ukur.

\section{Uji Korelasi}

Analisa korelasi digunakan untuk mengukur seberapa erat hubungan antara variabel bebas dengan variabel terikat. Dari hasli rekapitulasi dengan menggunakan SPSS dapat dilihat ditabel, sebagai berikut:

\section{Tabel 3}

\section{Analisa Korelasi}

\begin{tabular}{l|r|r|r|r|}
\hline Model & $\mathrm{R}$ & R Square & Adjusted R Square & $\begin{array}{c}\text { Std. Error of the } \\
\text { Estimate }\end{array}$ \\
\hline 1 & $.808^{\mathrm{a}}$ & .653 & .640 & .96118 \\
\hline
\end{tabular}
a. Predictors: (Constant), Suasanatempatberjualan, dayabelikonsumen,lokasi
Sumber: Data Primer yang Diolah, 2015


Dari uraian tabel 3.1. diatas maka dapat dibuktikan dengan hasil koefisien korelasi sebesar $\mathrm{R}=0,808$ atau $80,8 \%$. Besarnya koefisien korelasi ini semakin mendekati seratus persen dengan demikian hubungan antara Lokasi berjualan $\left(\mathrm{X}_{1}\right)$, Daya Beli Konsumen $\left(\mathrm{X}_{2}\right)$ serta Suasana tempat berjualan $\left(\mathrm{X}_{3}\right)$ terhadap keputusan pemilihan tempat berjualan di jl. HOS. Cokroaminoto Kediri (Y) sangat kuat karena mendekati angka 1, sedangkan nilai koefisien korelasi determinasi ( $\mathrm{R}$ Square) $=$ 0,653 yang berarti $65,3 \%$ faktor yang berpengaruh terhadap keputusan pemilihan tempat berjualan di jl. HOS. Cokroaminoto Kediri adalah Pemilihan Lokasi berjualan, Daya Beli Konsumen serta Suasana tempat berjualan, sedangkan sisanya sebesar $34,7 \%$ adalah faktor lain yang tidak diteliti dalam penelitian ini.

\section{Analisa Regresi Linear Berganda}

Analisa regresi linear berganda digunakan untuk mengetahui pengaruh antara beberapa variabel bebas X (Lokasi berjualan, Daya Beli Konsumen, Suasana) terhadap variabel Y (keputusan pemilihan lokasi berjualan di Jl. HOS. Cokroaminoto Kediri).

Dari hasil analisis regresi linier berganda antara variabel bebas dan variabel terikat dapat dilihat dari rekapitulasi sebagai berikut:

\section{Tabel 4}

\section{Analisa Regresi Linear Berganda}

Coefficients $^{\mathrm{a}}$

\begin{tabular}{|c|c|c|c|c|c|c|}
\hline \multirow{2}{*}{\multicolumn{2}{|c|}{ Model }} & \multicolumn{2}{|c|}{ Unstandardized Coefficients } & \multirow{2}{*}{$\begin{array}{c}\begin{array}{c}\text { Standardized } \\
\text { Coefficients }\end{array} \\
\text { Beta }\end{array}$} & \multirow[b]{2}{*}{$\mathrm{T}$} & \multirow[b]{2}{*}{ Sig. } \\
\hline & & $B$ & Std. Error & & & \\
\hline \multirow[t]{4}{*}{1} & (Constant) & 4.193 & 1.258 & & 3.332 & .001 \\
\hline & Lokasi & .314 & .066 & .428 & 4.776 & .000 \\
\hline & Daya Beli & .362 & .077 & .425 & 4.688 & .000 \\
\hline & Suasana & .117 & .057 & .137 & 2.037 & .045 \\
\hline
\end{tabular}

a. Dependent Variable: Keputusanpemilihanlokasiberjualan

Sumber: Data primer yang diolah, 2021

Dengan demikian persamaan garis regresinya, adalah: $\mathrm{Y}=4,193+0,314 \mathrm{X}_{1}+0,362 \mathrm{X}_{2}+0,117 \mathrm{X}_{3}$

Persamaan di atas dapat dijelaskan sebagai berikut:

a. Nilai konstanta sebesar 4,193 berarti jika variabel Lokasi berjualan, Daya Beli Konsumen, Suasana dianggap sama dengan nol, maka variabel keputusan PK5 memilih berjualan di Jl. HOS. Cokroaminoto Kediri sebesar 4,193.

b. Variabel Lokasi Berjualan $\left(\mathrm{X}_{1}\right)$ memiliki koefisien sebesar 0,314. Ini menunjukkan bahwa berpengaruh positif terhadap variabel keputusan PK5 memilih berjualan di Jl. HOS. Cokroaminoto Kediri. 
c. Variabel Daya Beli Konsumen $\left(\mathrm{X}_{2}\right)$ memiliki koefisien sebesar 0,362. Ini menunjukkan bahwa berpengaruh positif terhadap variabel keputusan PK5 memilih berjualan di J1. HOS. Cokroaminoto Kediri.

d. Variabel Suasana Tempat Berjualan $\left(\mathrm{X}_{3}\right)$ memiliki koefisien sebesar 0,117. Ini menunjukkan bahwa berpengaruh positif terhadap variabel keputusan PK5 memilih berjualan di J1. HOS. Cokroaminoto Kediri.

Dapat disimpulkan bahwa faktor Daya Beli Konsumen memiliki pengaruh yang dominan dibandingkan dengan faktor Lokasi Berjualan, dan Suasana tempat berjualan. Sehingga hipotesis dalam penelitian ini terbukti.

\section{Uji Hipotesis}

Analisa Uji F

Analisa Uji F di gunakan untuk mengetahui apakah variabel bebas secara simultan atau bersama-sama mempunyai pengaruh terhadap variabel terikatnya.

Dari hasil analisa SPSS diperoleh:

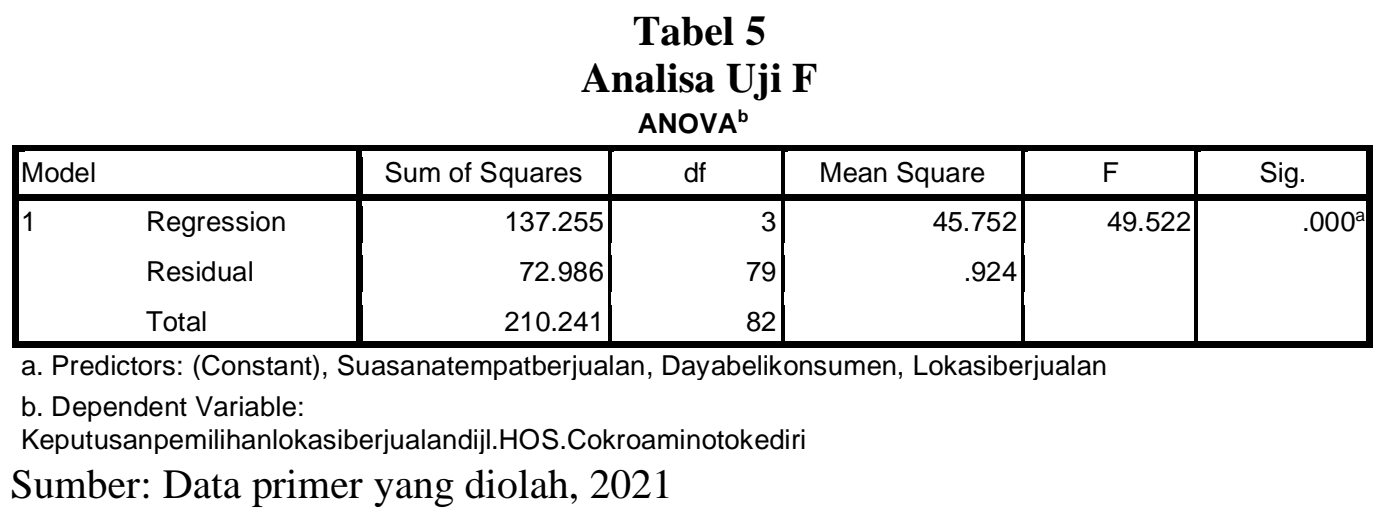

Dari tabel 5 diatas menunjukkan bahwa uji $\mathrm{F}$ hitung untuk variabel Lokasi Berjualan $\left(\mathrm{X}_{1}\right)$, Daya Beli Konsumen $\left(\mathrm{X}_{2}\right)$ serta Suasana Tempat Berjualan $\left(\mathrm{X}_{3}\right)$ sebesar 49,522 dengan menggunakan batas signifikan 0,05 maka diperoleh nilai signifikan sebesar 0,000 signifikan atau lebih kecil dari 0,05 yang berarti pengaruh ketiga variabel secara simultan terhadap keputusan PK5 memilih berjualan di Jl. HOS Cokroaminoto Kediri (Y) adalah signifikan. Dengan demikian maka Ho ditolak dan Ha yang menyatakan bahwa secara simultan variabel Lokasi Berjualan, Daya Beli Konsumen serta Suasana Tempat Berjualan berpengaruh terhadap keputusan PK5 memilih berjualan di Jl. HOS Cokroaminoto Kediri.

\section{Analisa Uji t}

Analisa uji t digunakan untuk mengetahui variabel bebas secara parsial atau individu terhadap variabel terikat. Besarnya t Hitung dari hasil penelitian yang dilakukan pada PK5 di Jalan HOS Cokroaminoto Kediri dapat dilihat pada tabel sebagai berikut: 


\section{Tabel 6}

Analisa Uji t

Coefficients $^{a}$

\begin{tabular}{|c|c|c|c|c|c|c|}
\hline \multirow{2}{*}{\multicolumn{2}{|c|}{ Model }} & \multicolumn{2}{|c|}{ Unstandardized Coefficients } & \multirow{2}{*}{$\begin{array}{c}\begin{array}{c}\text { Standardized } \\
\text { Coefficients }\end{array} \\
\text { Beta }\end{array}$} & \multirow[b]{2}{*}{$\mathrm{T}$} & \multirow[b]{2}{*}{ Sig. } \\
\hline & & B & Std. Error & & & \\
\hline \multirow[t]{4}{*}{1} & (Constant) & 4.193 & 1.258 & & 3.332 & .001 \\
\hline & Lokasiberjualan & .314 & .066 & .428 & 4.776 & .000 \\
\hline & Dayabelikonsumen & .362 & .077 & .425 & 4.688 & .000 \\
\hline & Suasanatempatjualan & .117 & .057 & .137 & 2.037 & .045 \\
\hline
\end{tabular}

a. Dependent Variable:

Keputusanpemilihanlokasiberjualandijl.HOS.Cokroaminotokediri

Sumber: Data primer yang diolah, 2021

Dari tabel 6 diatas maka dapat diketahui secara parsial variabel Lokasi berjualan $\left(\mathrm{X}_{1}\right)$ mempengaruhi variabel keputusan PK5 memilih berjualan di Jl. HOS. Cokroaminoto Kediri (Y), hal ini dapat kita ketahui dengan analisa uji $t$ hitung sebesar 4,776 pada probabilitas 0,000 yang lebih kecil dari 0,05 yang berarti sudah sangat signifikan. Serta variabel Daya Beli Konsumen $\left(\mathrm{X}_{2}\right)$ diperoleh t hitung 4.688 pada probabilitas 0,000 berarti juga sangat signifikan. Dan variabel Suasana Tempat Berjualan $\left(\mathrm{X}_{3}\right)$ diperoleh thitung 2,037 pada probabilitas 0,045 berarti juga sangat signifikan. Maka bisa dijelaskan bahwa faktor-faktor internal perilaku konsumen yang terdiri dari Lokasi Berjualan $\left(\mathrm{X}_{1}\right)$, Daya Beli Konsumen $\left(\mathrm{X}_{2}\right)$, serta Suasana Tempat Berjualan $\left(\mathrm{X}_{3}\right)$ mempunyai hubungan terhadap keputusan PK5 memilih berjualan di Jalan HOS Cokroaminoto Kediri. Hasil pengujian menggunakan regresi linier berganda menunjukkan bahwa variabel Lokasi Berjualan $\left(\mathrm{X}_{1}\right)$, Daya Beli Konsumen $\left(\mathrm{X}_{2}\right)$, serta Suasana Tempat Berjualan $\left(\mathrm{X}_{3}\right)$ mempunyai mempunyai pengaruh yang positif terhadap terhadap keputusan PK5 memilih berjualan di Jalan HOS Cokroaminoto Kediri.

\section{Simpulan}

Berdasarkan dari hasil pembahasan dan hasil perhitungan yang telah dilakukan oleh peneliti dalam penelitian ini, maka dapat disimpulkan hasil pengujian menggunakan statistik diketahui koefisien korelasi berganda sebesar 0,808. Hal ini menunjukkan bahwa faktor-faktor internal prilaku konsumen yang terdiri dari Lokasi Berjualan $\left(\mathrm{X}_{1}\right)$, Daya Beli Konsumen $\left(\mathrm{X}_{2}\right)$, dan Suasana Tempat Berjualan $\left(\mathrm{X}_{3}\right)$ mempunyai hubungan terhadap keputusan PK5 memilih berjualan di Jalan HOS Cokroaminoto Kediri. Hasil pengujian dengan regresi linier berganda diketahui persamaan regresi berpengaruh antara Lokasi Berjualan $\left(\mathrm{X}_{1}\right)$, Daya Beli Konsumen $\left(\mathrm{X}_{2}\right)$, dan Suasana Tempat Berjualan $\left(\mathrm{X}_{3}\right)$ adalah $\mathrm{Y}=4,193+0,314 \mathrm{X}_{1}$ $+0,362 X_{2}+0,117 X_{3}$. Dari variabel Lokasi Berjualan $\left(X_{1}\right)$, Daya Beli Konsumen $\left(\mathrm{X}_{2}\right)$, dan Suasana Tempat Berjualan $\left(\mathrm{X}_{3}\right)$. Variabel Daya Beli Konsumen lebih 
berpengaruh dominan dengan koefisien regresi 0,362. maka hipotesis penelitian terbukti. Sedangkan varibel Lokasi Berjualan koefisien regresi 0,314, dan Suasana Tempat Berjualan koefisien regresi 0,117. Dapat disimpukan bahwa variabel X2, Daya beli konsumen bepengaruh paling dominan terhadap keputusan PK5 memilih berjualan di Jalan HOS Cokroaminoto Kediri.

\section{Daftar Pustaka}

Bennet, P. D. (1988). Dictionary of Marketing Terms (p. 72-78) New York: The American marketing association.

Baker, J., Girewal, D. and Parasuraman, A. (1994), "The Influence of the Store Environment on Quality Inferences and Store Image", Journal of the Academy of Marketing Science”, Vol. 22, Fall, pp.328-39.

Basu Swastha. (2000). Pengantar Bisnis Modern, Pengantar Ekonomi Perusahaan Modern, Jakarta: Liberty.

Bayu Pramutoko. (2014). Manajemen Pemasaran. Kediri: Penerbit Dimar Intemedia

Bayu Pramutoko. (2015). Ekonomi Makro. Kediri: Penerbit Dimar Intemedia

Chandra Gregorius (2002), Strategi Dan Program Pemasaran, Penerbit Andi, Yogyakarta

Daharmesta, B.S. \& dan Handoko, T.H. (1987), Manajemen Pemasaran; Analisis Perilaku Konsumen (p.45). Yogyakarta: Penerbit Liberty

Dolan R.J. (1991). Strategic Marketing Management (p. 86). Boston: Harvard Business School Publications.

Djaslim, Saladin dan Yevis Marty Oesman. (2002). Intisari Pemasarandan Unsur - Unsur Pemasaran, Cetakan Kedua, Bandung: Penerbit Linda Karya.

Durianto, D. dan C. Liana. (2004). Analisi efektivitas iklan televisi softener soft \& fresh di Jakarta dan sekitarnya dengan menggunakan consumen decision model, Jurnal Ekonomi Perusahaan, Vol.11 (no.1): 35-55 Dipublikasikan.

Engel JF, et al. (1990). Consumer Behavior, 6th ed (p.5). Chicago: Chicago the Dryden Press Kotler, P. (1996). Manajemen Pemasaran Analisis Perencanaan Implementasi dan Pengendalian (p.54). Jakarta: Fakultas Ekonomi Universitas Indonesia.

Empat. Griffin, Jill. (2002). Customer Loyality.Jakarta: Erlangga.

Engel, James F, Blackwell, Roger D, and Miniard, Paul W. (2005), Perilaku Konsumen, Terjemahan Budiyanto. Jakarta: Binarupa Aksara.

Griffin, Ricky W dan Ronald J. Ebert. (2007). Bisnis Edisi Kedelapan. Jakarta :Erlangga.

Kotler, Philip. (2002). Manajemen Pemasaran. (Edisi Millenium 2), Terjemahan. Jakarta: Prehalindo 